D. S. Alfred-Ugbenbo, O. A. Zdoryk, V. A. Georgiyants

National University of Pharmacy

\title{
PRESCRIPTION ANALYSIS FOR EXTEMPORANEOUS PREPARATIONS IN HOSPITAL PHARMACIES OF SOUTHERN NIGERIA
}

Today community and hospital pharmacies worldwide (including Nigeria) experience an increased demand for extemporaneous preparations. Due to "per body weight" dosing system, difficulty in swallowing, frailty in organs of metabolism and unavailability of required dosage forms, the reconstitution/ tailoring of medications to individual patients needs has become necessary. In Nigeria most ( $>95 \%$ ) of the extemporaneously prepared medications are oral dosage forms. It is a common practice for these medications to be prepared from a commercially available oral solid dosage form by crushing tablets or mixing contents with a dispersion medium (base/vehicle). The aim of the work was to analyse frequently compounded prescriptions in south-south geopolitical region of Nigeria, bases/vehicles used in compounding and stability study concerns of compounded preparations. For this purpose a survey of prescriptions in hospital pharmacies in the south-south geopolitical region of Nigeria was conducted. The prescriptions that required extemporaneous preparation were selected and sorted into active pharmaceutical ingredients (APIs), doses, regime and duration of treatment. Most prescribed preparations that required compounding include antibiotics (24.9\%) and drugs indicated for cardiovascular diseases (60.0\%). While the treatment duration prescribed for extemporaneous preparations ranged from two days to a month, the most recurring duration was one week. Syrups of ascorbic acid and Vitamin B Complex were occasionally used as bases for compounding, but stability study of extemporaneous preparations made from these medicated syrups is yet to be conducted in Nigeria. APIs as part of commercial drugs were mostly (92.9\%) used in compounding. Stability study of extemporaneous preparations in Nigeria is an urgent problem that needs to be resolved.

Key words: Extemporaneous preparations; active pharmaceutical ingredient; base/vehicle; survey; syrups; stability

\section{STATEMENT OF THE PROBLEM}

Today extemporaneous preparations find greater use in community and hospital pharmacies worldwide, including Nigeria. This is chiefly due to reconstitution/tailoring of medications to individual patients needs either by reason of "per body weight" dosing system, difficulty in swallowing, frailty in organs of metabolism or unavailability of required dosage forms. In Nigeria most ( $>95 \%$ ) of the extemporaneously prepared medications are oral dosage forms.

\section{ANALYSIS OF RECENT RESEARCH} AND PUBLICATIONS

In Nigeria, USA, Australia, Malaysia and some European countries, it is a common practice for these medications to be prepared from a commercially

(c) Alfred-Ugbenbo D. S., Zdoryk O. A., Georgiyants V. A., 2016 available oral solid dosage form by crushing tablets or mixing contents with a dispersion medium (base/vehicle) [2, 9, 12-16]. According to the British Pharmaceutical Codex, medicated and flavouring syrups provide a convenient form of stock solution of certain drugs for use in extemporaneous preparations [3].

\section{IDENTIFICATION OF ASPECTS OF THE PROBLEM UNSOLVED PREVIOUSLY}

While other nations have progressed with finding solutions to this not so recent development, stakeholders in Nigeria are yet to give the much needed attention. For stability studies to be undertaken for compounded preparations, one must sort out the local needs of the region in terms of frequently prescribed medications, cost and availability of components of extemporaneous preparations etc. 


\section{INDICATIONS FOR WHICH MEDICINES WERE COMPOUNDED AND NUMBER PRESCRIBED WITHIN A 19-MONTH PERIOD}

\begin{tabular}{|c|c|c|c|}
\hline \multirow{2}{*}{ Drugs } & \multirow{2}{*}{ Indications } & \multicolumn{2}{|c|}{ Number of prescriptions } \\
\hline & & $\mathrm{XGH}$ & UPTH \\
\hline Acetazolamide & Glaucoma, drug-induced oedema & 7 & 78 \\
\hline Amlodipine & Antihypertension & 5 & - \\
\hline Captopril & Antihypertension & 9 & 46 \\
\hline Chlorpromazine & Antipsychosis, nausea and vomiting & 6 & - \\
\hline Cimetidine & Gastroesophogeal reflux & 14 & - \\
\hline Ciprofloxacin & $\begin{array}{l}\text { Chronic suppurative otitis media(with sensitivity to } \\
\text { ciprofloxacin), chronic diarrhoea, GET, other bacterial } \\
\text { infections }\end{array}$ & 98 & 195 \\
\hline Digoxin & Arrhythmia, heart failure & 45 & - \\
\hline Enalapril & $\begin{array}{l}\text { Hypertension; symptomatic heart failure, prevention of } \\
\text { symptomatic heart failure in patients with asymptomatic left } \\
\text { ventricular dysfunction }\end{array}$ & - & 8 \\
\hline Furosemide & Oedema in CHF and renal disease & 11 & - \\
\hline Hydrochlorothiazide & Acute glomerular nephritis & 39 & - \\
\hline Hydroxyurea & Melanoma, sickle-cell disease, chronic myeloid leukaemia & 11 & - \\
\hline Isoniazid & Tuberculosis & 6 & - \\
\hline Morphine & Pain management & 1 & - \\
\hline Nevirapine & HIV/AIDS & 7 & - \\
\hline Nitrofurantoin & Urinary tract infections & - & 5 \\
\hline Omeprazole & Gastroesophogeal reflux, duodenal ulcer & - & 13 \\
\hline Pyridoxine & Vitamin B6 deficiency & 1 & - \\
\hline Ranitidine & Gastroesophogeal reflux & 3 & - \\
\hline Rifampicin & Tuberculosis & 5 & - \\
\hline Spironolactone & Oedema in heart failure, hypertension, nephrotic syndrome & 74 & 456 \\
\hline Tramadol & Opioid analgesic & - & 14 \\
\hline \multicolumn{2}{|l|}{ Total } & 342 & 815 \\
\hline
\end{tabular}

\section{OBJECTIVE STATEMENT OF THE ARTICLE}

The aim of the work was to analyse frequently compounded prescriptions in south-south geopolitical region of Nigeria, stability study concerns of compounded preparations and bases/vehicles used in compounding.

\section{PRESENTATION OF THE MAIN MATERIAL OF THE RESEARCH}

The study was conducted using prescriptions obtained from the University of Port-Harcourt Teaching Hospital, Rivers State (UPTH) and another major hospital in the southern part of Nigeria, which preferred to remain anonymous (XGH). A combination of closed and open-ended format questionnaire, distributed to pharmacists in the UPTH, was used to obtain information on APIs and vehicles/ bases used in compounding and its cost. Data from both prescriptions and questionnaire were analysed into Microsoft Excel 2010 and summarized in tables.

A total of 1157 relevant prescriptions from the period of January 2014 - September 2015 were assessed for the study. Hospital XGH allowed access to information on compounded prescriptions under the conditions of anonymity but did not give permission to conduct a questionnaire survey. A total of 42 out of 43 questionnaires distributed to compounding pharmacists were returned, representing a $97.7 \%$ response rate of the sample size. Mean scores were determined for each item and the summarized data presented below.

Frequently compounded medications in the southern part of Nigeria. These include active pharmaceutical ingredients (APIs) used in gastroenterological (cimetidine, ranitidine, omeprazole), cardiovascular (amlodipine, captopril, digoxin, enalapril) and antimicrobial (ciprofloxacin) diseases; diuretics (furosemide, spironolactone, hydrochlorothiazide); antineoplastics (hydroxyurea); vitamins (pyridoxine); antituberculosis (rifampicin, isoniazid); opioid analgesics (tramadol); urinary anti-infectives (nitrofurantoin) and anti-HIV (nevirapine).

From Fig., ciprofloxacin and spironolactone are the most frequently compounded prescriptions for XGH and UPTH respectively. These drugs are indicative of infectious diseases and ailments associated with the cardiovascular system. Other frequently compounded drugs include digoxin, hydro- 
УПРАВЛІННЯ, ЕКОНОМІКА ТА ЗАБЕЗПЕЧЕННЯ ЯКОСТІ В ФАРМАЦІІ, № 3 (47) 2016

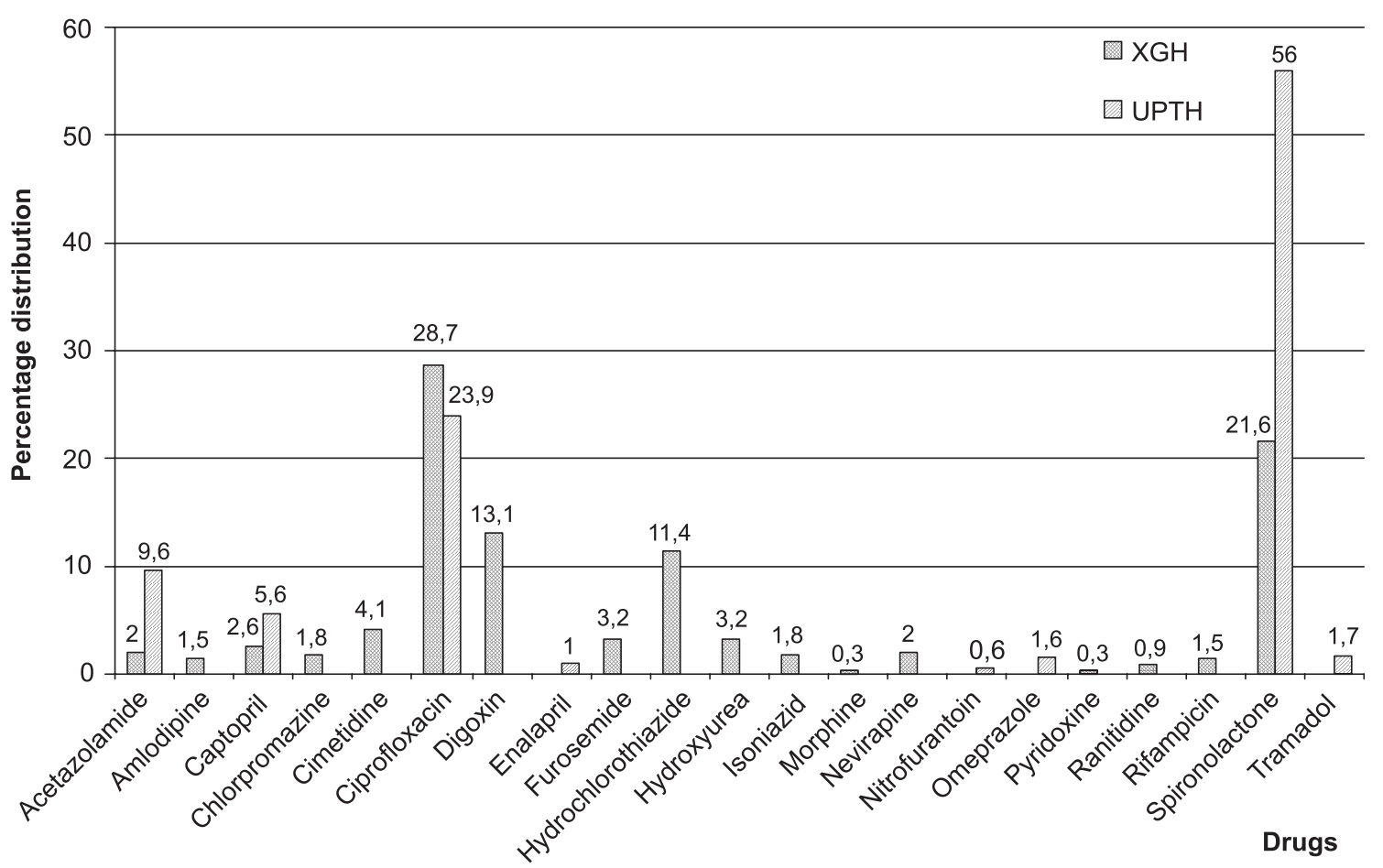

Fig. Percentage distribution of compounded drugs in XGH and UPTH

Table 2

SOME OF THE DOSES FOR WHICH COMPOUNDING WAS REQUIRED IN XGH

\begin{tabular}{|c|c|c|c|c|}
\hline Drug & Fixed dose (tab/caps) & $\begin{array}{l}\text { Required (prescribed) } \\
\text { dose }\end{array}$ & Regime & Age \\
\hline Acetazolamide & $500 \mathrm{mg} / 250 \mathrm{mg}$ & $80 \mathrm{mg}, 47.2 \mathrm{mg}$ & Tds $\times 1 / 52$ & $2-12 / 12$ \\
\hline Amlodipine & $10 \mathrm{mg} / 5 \mathrm{mg} / 2.5 \mathrm{mg}$ & $3.6 \mathrm{mg}$ & Od $\times 2 / 52$ & $8-10$ years \\
\hline Captopril & $50 \mathrm{mg} / 25 \mathrm{mg} / 12.5 \mathrm{mg}$ & $1 \mathrm{mg}, 0.4 \mathrm{mg}$ & $\operatorname{Tds} \times 5 / 7, \mathrm{Bd} \times 1 / 52$ & $\begin{array}{l}2-7 / 12 \\
\text { Neonate }\end{array}$ \\
\hline Chlorpromazine & $100 / 50 / 25 / 10 \mathrm{mg}$ & $1.4 \mathrm{mg}$ & $\mathrm{Qds} \times 2 / 52$ & $9 / 7,1-5 / 12$ \\
\hline Cimetidine & $800 \mathrm{mg} / 400 \mathrm{mg} / 200 \mathrm{mg}$ & $29.5 \mathrm{mg}, 67 \mathrm{mg}$ & $\mathrm{Bd} \times 1 / 52, \mathrm{Tds} \times 1 / 52$ & $2-8 / 12$ \\
\hline Ciprofloxacin & $500 \mathrm{mg}$ & $\begin{array}{l}150 \mathrm{mg}, 90 \mathrm{mg} .52 \mathrm{mg}, \\
45 \mathrm{mg}, 105 \mathrm{mg}\end{array}$ & $\begin{array}{l}\mathrm{Bd} \times 5 / 7, \mathrm{Bd} \times 1 / 52, \mathrm{Bd} \times 2 / 52 \\
\mathrm{Bd} \times 10 / 7, \mathrm{Bd} \times 2 / 7\end{array}$ & $\begin{array}{l}2-18 / 12 \\
5 \text { years }\end{array}$ \\
\hline Digoxin & $250 \mathrm{mcg}$ & $\begin{array}{l}260 / 130 / 130 / 65 \mathrm{mg}, \\
80 / 40 / 40 / 20 \mathrm{mg}, 240 \mu \mathrm{g}\end{array}$ & $\begin{array}{l}\text { Stat/8hrs/16hrs/bd, } \\
\mathrm{Bd} \times 1 / 52\end{array}$ & $\begin{array}{l}2 / 7,3-6 / 12, \\
8 \text { years }\end{array}$ \\
\hline Frusemide & $40 \mathrm{mg} / 20 \mathrm{mg}$ & $4 \mathrm{mg}, 8 \mathrm{mg}$ & $\mathrm{Bd} \times 1 / 52$ & $\begin{array}{l}\text { Neonate, } \\
2-5 / 12\end{array}$ \\
\hline $\begin{array}{l}\text { Hydrochloro- } \\
\text { thiazide }\end{array}$ & $50 \mathrm{mg} / 25 \mathrm{mg} / 12.5 \mathrm{mg}$ & $8 \mathrm{mg}, 16.2 \mathrm{mg}, 20.2 \mathrm{mg}$ & $\mathrm{Bd} \times 1 / 52, \mathrm{Od} \times 1 / 52$ & $\begin{array}{l}12-19 / 12, \\
9 \text { years }\end{array}$ \\
\hline Hydroxyurea & $500 \mathrm{mg}$ & $240 \mathrm{mg}, 250 \mathrm{mg}$ & Od $\times 2 / 52$ & $\begin{array}{l}12-17 / 12, \\
\text { adult }\end{array}$ \\
\hline Isoniazid & $300 \mathrm{mg} / 100 \mathrm{mg}$ & $80 \mathrm{mg}$ & Od x $1 / 52$ & 4-6 years \\
\hline Nevirapine & $200 \mathrm{mg}$ & $15 \mathrm{mg}, 36 \mathrm{mg}$ & $\mathrm{Bd} \times 2 / 52$ & $1-3 / 12$ \\
\hline Pyridoxine & $\begin{array}{l}200 \mathrm{mg} / 100 \mathrm{mg} / 50 \\
\mathrm{mg} / 25 \mathrm{mg}\end{array}$ & $12.5 \mathrm{mg}$ & Od $\times 2 / 52$ & $9 / 7$ \\
\hline Ranitidine & $300 \mathrm{mg} / 150 \mathrm{mg}$ & $26 \mathrm{mg}$ & $\mathrm{Bd} \times 1 / 52$ & $2-3$ years \\
\hline Rifampicin & $300 \mathrm{mg} / 150 \mathrm{mg}$ & $120 \mathrm{mg}$ & Od x $1 / 52$ & 4-6 years \\
\hline Spironolactone & $100 \mathrm{mg} / 50 \mathrm{mg} / 25 \mathrm{mg}$ & $\begin{array}{l}10.2 \mathrm{mg}, 11.8 \mathrm{mg} \\
20.2 \mathrm{mg}, 5.2 \mathrm{mg}\end{array}$ & $\begin{array}{l}\mathrm{Od} \times 1 / 52, \mathrm{Bd} \times 1 / 52, \\
\mathrm{Bd} \times 2 / 52\end{array}$ & $\begin{array}{l}3 / 12,8 / 12 \\
19 / 12,2 / 52\end{array}$ \\
\hline
\end{tabular}

Key: 3/7 - three days, 3/52 - three weeks, 3-4/12 - three to four months, Od - once daily, Bd - twelve hourly, Tds - eight hourly, Qds - six hourly, Stat-immediately. 
SOME OF THE DOSES FOR WHICH COMPOUNDING WAS REQUIRED IN UPTH

\begin{tabular}{|c|c|c|c|c|}
\hline Drug & Fixed dose (tab/cap) & $\begin{array}{l}\text { Required (prescribed) } \\
\text { dose }\end{array}$ & Regime & Age \\
\hline Acetazolamide & $500 \mathrm{mg} / 250 \mathrm{mg}$ & $\begin{array}{l}12.5 \mathrm{mg}, 20 \mathrm{mg} \\
25 \mathrm{mg}, 100 \mathrm{mg}\end{array}$ & $\begin{array}{l}\mathrm{Bd} \times 1 / 52, \mathrm{Bd} \times 2 / 52, \\
\mathrm{Bd} \times 1 / 12\end{array}$ & $2-15 / 12,3$ years \\
\hline Captopril & $50 \mathrm{mg} / 25 \mathrm{mg} / 12.5 \mathrm{mg}$ & $3.125 \mathrm{mg}$ & $\begin{array}{l}\mathrm{Bd} \times 5 / 7, \mathrm{Bd} \times 1 / 52 \\
\mathrm{Bd} \times 1 / 12\end{array}$ & $2-9 / 12,1$ year \\
\hline Ciprofloxacin & $500 \mathrm{mg}$ & $\begin{array}{l}70 \mathrm{mg}, 100 \mathrm{mg}, 150 \mathrm{mg}, \\
160 \mathrm{mg}, 170 \mathrm{mg}\end{array}$ & Od $\times 3 / 7$ & $\begin{array}{l}7-12 / 12,2 \text { years, } \\
4 \text { years }\end{array}$ \\
\hline Enalapril & $20 \mathrm{mg} / 10 \mathrm{mg} / 5 \mathrm{mg}$ & $3.125 \mathrm{mg}$ & $\mathrm{Bd} \times 1 / 52, \mathrm{Bd} \times 1 / 12$ & $2 / 12,3$ years \\
\hline Nitrofurantoin & $100 \mathrm{mg} / 50 \mathrm{mg} / 25 \mathrm{mg}$ & $20 \mathrm{mg}, 30 \mathrm{mg}, 40 \mathrm{mg}$ & $\begin{array}{l}\text { Bd x } 1 / 52, \text { Tds } \times 1 / 52, \\
\text { Od } \times 1 / 52, \text { Nocte } \times 2 / 52\end{array}$ & $\begin{array}{l}1-9 / 12,2 \text { years, } \\
11 \text { years }\end{array}$ \\
\hline Omeprazole & $40 \mathrm{mg} / 20 \mathrm{mg}$ & $10 \mathrm{mg}$ & Od x $1 / 52$ & 4-10 years \\
\hline Spironolactone & $100 \mathrm{mg} / 50 \mathrm{mg} / 25 \mathrm{mg}$ & $3.125 \mathrm{mg}$ & $\begin{array}{l}\mathrm{Bd} \times 1 / 52, \mathrm{Bd} \times 2 / 52 \\
\mathrm{Bd} \times 1 / 12\end{array}$ & $2-3 / 12$ \\
\hline Tramadol & $100 \mathrm{mg} / 50 \mathrm{mg}$ & $25 \mathrm{mg}$ & $\mathrm{Bd} \times 5 / 7$ & 4-7 years \\
\hline
\end{tabular}

Key: $3 / 7$ - three days, $3 / 52$ - three weeks, 3-4/12 - three to four months, Od - once daily, Bd - twelve hourly, Tds - eight hourly, Qds - six hourly, Nocte - at night.

chlorothiazide, furosemide, acetazolamide and captopril.

At XGH (Tab. 2), the most recurring duration (regime) for which the compounded drugs were prescribed was one week while the maximum duration was two weeks. In UPTH (Tab. 3), the most recurring duration was also one week while the maximum duration was for one month.

It was observed that most of the extemporaneous preparations in UPTH are made using APIs from commercial drugs. Although imported bases/ vehicles (ORA-Plus, ORA-Sweet etc.) are used, pharmacists admit to have used (one time or the other in their years of practice) locally available medicated syrups (LAMS) as dispersion medium for prescribed active components. Compounding in Nigeria is done majorly in hospital pharmacies. This writer and majority of pharmacists are not aware of any stability tests on extemporaneous formulations conducted in/for the country.

Stability concerns. Hitherto, there hasn't been a stability study of extemporaneous preparations made from these medicated syrups in Nigeria. Syrups of ascorbic acid and Vitamin B Complex have been occasionally (frequently in some cases) used [1] although stability tests haven't been conducted or made available.

Some internationally published stability tests have been conducted using APIs from specific commercial drugs $[4,7,15,16]$. However, one cannot guarantee that all compounding pharmacists (worldwide) make use of those APIs from specific pharmaceutical firms with which stability test was conducted. Rather, there is a greater possibility that APIs of commercial drugs used by most compounding pharmacists may be different from those used in successfully carried out and published stability data.

Secondly, different pharmaceutical firms use different excipients in producing one and the same class of drugs [6]. Absence of a standard recipe and APIs (of commercial fixed-dose drugs) of specific pharmaceutical firms paves the way for use of different APIs and dispersion media of which different excipients may constitute. This produces different risks in stability $[8,19]$ and consequently, increase uncertainty in allocated beyond-use-dates (BUDs).

The APIs generally used for compounding in hospital pharmacies in Nigeria are commercially available fixed-dose drugs (tablets, capsules, injections etc). Pure substances (as APIs) for compounding are rarely purchased. All drugs, extemporaneously prepared in the hospitals were packaged in well closed amber bottles to prevent photolabile degradation [9]. Patients were advised to store at recommended temperatures and away from children's reach. Suspensions were labelled "shake well before use".

Prospective substitutes. Not all hospital pharmacies in the country use imported vehicles (IMPVs) such as ORA-Sweet, ORA-Sweet SF, ORA-Plus, Cherry syrup etc. in compounding. During shortage of supply, patients won't be turned away [5]; hospital pharmacies may have to improvise by using alternative vehicles for dispersing prescribed APIs. This leaves the option of locally readily available syrups (LAMSs) such as medicated syrups of ascorbic and Vitamin B complex. It is imperative that such tests be carried out for these syrups since they have occasionally been used. The results of these tests will provide assured BUDs. The problem of 
palatability of compounded formulation is significantly alleviated with the sweet taste of LAMSs which masks unpleasant taste of APIs.

Cost Benefits of Prospective Alternatives. The average cost of the LAMSs $(60-100 \mathrm{ml})$ is within the range of $\$ 0.7-\$ 0.8$ (United States Dollars), while cost for $100 \mathrm{ml}$ equivalent of ORA-Plus, ORA-Sweet, ORA-Sweet SF and BLEND (excluding shipment) in the United States goes for $\$ 4.10$.

Market price of $16 \mathrm{oz}$ IMPVs $(473.176 \mathrm{ml})$ is $\$ 19.41$

$100 \mathrm{ml}(3.38 \mathrm{oz})$ of IMPV $=\$ 4.10$

The costs of IMPVs exceed the LAMSs 4.5 times, excluding shipment/mark-up. Considering the cost benefits and availability of LAMSs, they serve as potential alternatives to IMPVs.

For a population with $30 \%$ below the poverty line of $\$ 1.25$ power purchasing parity (PPP) [20], affordability of drugs is a significant factor in total therapeutic outcome.

At $\mathrm{XGH}$, the most frequent duration (regime) for which the compounded drugs were prescribed was one week while the maximum duration was two weeks. In UPTH, the most frequent duration is also one week while the maximum duration was one month. If these LAMSs could maintain the integrity of the APIs for a month, they will serve as a readily available substitute. In a situation where the APIs are stable for two weeks or 10 days, the patients could be asked to come for a refill when the conservative BUD approaches.

Most of the prescriptions have an average duration of seven to ten days (Tab. 2). This is to help physicians assess response to treatment or reduction of disease indicators. Also, it encourages adherence/compliance to treatment, which becomes difficult when prescription is for a long duration [18]. Nigerian parents are not comfortable either taking their children for prolonged visits or leaving their children in hospitals beyond two weeks. Oftentimes alternative solutions to health problems are sought after $[7,10,17]$. They include spiritual (prayers and prayer houses), local massage therapists, proven and unproven herbal (non-orthodox) formulations sold by vendors.

Based on the average duration in table 2 and 3 , initial/low-cost stability tests could be conducted for up to 40 days maximum, for which BUDs could be established.

\section{CONCLUSIONS AND PROSPECTS FOR FURTHER RESEARCH}

Based on the analysis of frequently compounded prescriptions, ciprofloxacin, spironolactone, digoxin, hydrochlorothiazide, acetazolamide, furosemide and captopril constitute majority of extemporaneous medications prepared in these hospitals. The APIs used for compounding in hospital pharmacies in southern Nigeria are commercially available fixeddose drugs (tablets, capsules and injections).

Oral dosage forms make up more than $99 \%$ of extemporaneous prescriptions analysed in these hospitals. Imported vehicles/bases such as ORA-Sweet, ORA-Sweet SF, ORA-Plus and Cherry syrup, used as the dispersion media, are more expensive than the proposed cheaper locally available medicated syrups. In order to reduce cost of these extemporaneously prepared medications the vehicles/bases have to be replaced by cheaper locally available medicated syrups.

Where successful stability studies have been conducted using APIs of commercially available drugs (of specific pharmaceutical firms), such APIs should be preferably used in formulation of compounded preparations; as APIs of different firms may be constituted of different excipients which may not produce the same shelf-life. The same applies when and if proposed medicated syrups pass stability tests. It is pertinent that government, hospital and all stakeholders in the Nigeria pay more attention to funding for stability tests and full equipment of compounding laboratories.

\section{REFERENCES}

1. Aghahowa S. E. Pattern of extemporaneous prescriptions and preparations in a tertiary health institution: a five-year assessment / S. E. Aghahowa, J. O. Egharevba, B. E. Erhagbe, F. Okoh // Intern. J. of Pharm. Compounding. - 2013. - № 5 (17). - P. 432-435.

2. Bolisetty $\mathrm{S}$. Omeprazole $2 \mathrm{mg} / \mathrm{ml}$ suspension. South eastern Sydney local health district / S. Bolisetty, E. Jozsa. [Electronic resource]. - Режим доступа: http://www.seslhd.health. nsw.gov.au/rhw/newborn_care/guidelines/ medication/pdf/omeprazole.pdf.

3. British Pharmaceutical Codex (1979) $11^{\text {th }}$ Ed. - London: The Pharmaceutical Press, 1979. P. 791 .

4. Chan D. S. Degradation of captopril in solutions compounded from tablets and standard powder / D. S. Chan, A. K. Sato, J. R. Claybaugh // Am. J. Hosp. Pharm. - 1994. - № 51. - P. 1205-1207.

5. Crawford S. Y. Extemporaneous compounding activities and the associated informational needs of pharmacist / S. Y. Crawford, S. R. Dombrowski // Am. J. Hosp. Pharm. - 1991. № 48. - P. 1205-1210.

6. Davit B. M. Comparing generic and innovator drugs: a review of 12 years of bioequivalence data from the United States Food and Drug Administration / [B. M. Davit, P. E. Nwaka- 
ma, G. I. Buehler et al.] // Ann. Pharmacother. - 2009. - № 43 (10). - P. 1583-1597.

7. Elujoba A. A. Traditional medicine development for medical and dental primary health care delivery system in Africa / A. A. Elujoba, O. M. Odeleye, C. M. Ogunyemi // African J. of Traditional, Complementary and Alternative Med. - 2005. - № 2 (1). - P. 46-61.

8. Glass B. D. Stability considerations in liquid dosage forms extemporaneously prepared from commercially available products / B. D. Glass, A. Haywood // J. of Pharmacy and Pharm. Sci. - 2006. - № 9. - P. 398-426.

9. Jackson M. Handbook of Extemporaneous Preparation: A Guide to Pharmaceutical Compounding / M. Jackson, A. Lowey. - London: Pharmaceutical Press, 2010. - 464 p.

10. Kisangau D. P. Traditional knowledge, use practices and conservation of medicinal plants for HIV/AIDS care in rural Tanzania / [D. P. Kisangau, T. M. Herrmann, H. V. Lyaruu et al.] // Ethnobotany Res. and Applications. - 2011. - № 9. - P. 43-58.

11. Li Y. Y. Development of a hydrochlorothiazide $0,5 \mathrm{mg} / \mathrm{mL}$ oral solution for children / Y. Y. Li, D. J. Postma, H. W. G. Wagenaar // EAHP Congress, Paris, 2013. [Electronic resource]. - Режим доступа: http://www.stabilis.org/ FichesBiblio/ 3399.pdf.

12. Loyd V. A. Current \& Practical Compounding Information for the Pharmacist / V. A. Loyd // Secundum Artem. - 2012. - № 17 (1). P. 1-4.

13. Lye M. Y. Effects of ingredients on stability of captopril in extemporaneously prepared oral liquids / [M. Y. Lye, K. L. Yow, L. Y. Lim et al.] // Am. J. Health-Syst. Pharm. - 1997. № 54. - P. 2483-2487.

14. МOH Extemporaneous Formulary 2011 [Електронний ресурс]. - Режим доступу: http:// www.pharmacy.gov.my/v2/sites/default/ files/document-upload/mohextemporaneousformulary-2011.pdf

15. Nahata M. C. Stability of amlodipine mesylate in two liquid dosage form / M. C. Nahata, R. S. Morosco, T. F.Hipple // J. Am. Pharm. Assoc. - 1999. - № 39. - P. 375-377.

16. Nahata M. C. Stability of captopril in liquid containing ascorbic acid or sodium ascorbate / M. C. Nahata, R. S.Morosco, T. F. Hipple // Am. J. Hosp. Pharm. - 1994. - № 51. P. 1707-1708.

17. Pauline E. O. Complementary and alternative medicine in the management of hypertension in an urban Nigerian community / E. O. Pauline, E. O. Bernard // BMC Complementary and Alternative Medicine. - 2010. - № 10. - P. 1-9.

18. Rasaq A. Treatment non-adherence among patients with poorly controlled type 2 diabetes in ambulatory care settings in south western $\mathrm{Ni}$ geria / A. Rasaq, O. F. Titilayo // Afr. Health Sci. - 2014. - № 14 (1). - P. 1-10.

19. Trissel L. A. Trissel's stability of compounded formulations. -4 th ed. - Washington, DC: American Pharmacists Association, 2009. - 654 p.

20. United Nations Framework Convention on Climate Change: Nigeria's intended nationally determined contribution, Cairo 2015. [Електронний ресурс]. - Режим доступу: http://www4.unfccc.int/submissions/INDC/ Published\% 20Documents/Nigeria/1/Approved $\%$ 20Nigeria's $\%$ 20INDC_271115.pdf.

\section{Acknowledgement}

The authors thank the administration and staff of the University of Port- Harcourt Teaching Hospital Rivers State for their guide and cooperation in assessing needed information. 
УДК 615.014.2:615.2:615.451.2:615.11/.12

Д. С. Альфред-У гбенбо, А. А. Здорик, В. А. Георгіянц

АНАЛИЗ РЕЦЕПТУРЫ ЭКСТЕМПОРАЛЬНЫХ ЛЕКАРСТВЕННЫХ СРЕДСТВ

В ГОСПИТАЛЬНЫХ АПТЕКАХ ЮЖНОЙ НИГЕРИИ

В настоящее время экстемпоральные лекарственные средства все больше пользуются спросом и изготавливаются в коммунальных и госпитальных аптеках во всем мире, в том числе и Нигерии. Это объясняется главным образом потребностью индивидуального приготовления лекарственных средств из-за веса тела, подбора дозировки, трудностей при глотании, недостатка обмена веществ или отсутствия необходимых лекарственных форм. В Нигерии большинство (>95%) экстемпоральных лекарственных средств является пероральными лекарственными формами. Обычной практикой для этих лекарственных средств является их приготовление из коммерчески доступных пероральных твердых лекарственных форм путем измельчения таблеток или смешивания содержимого с дисперсной средой (основой/наполнителем). Целью работы был анализ номенклатуры прописей, наиболее часто изготавливаемых на юге Нигерии, проблем изучения стабильности лекарственных средств аптечного изготовления, перечня оснований/наполнителей, используемых при изготовлении. С этой целью было проведено анкетирование работников госпитальных аптек в юго-южном геополитическом регионе Нигерии. Прописи, которые требовали экстемпорального изготовления, были отобраны и рассортированы в зависимости от активных фармацевтических ингредиентов, дозировки, режима и продолжительности лечения. Наиболее часто прописываются лекарственные средства аптечного изготовления, содержащие антибиотики (24.9 \% ), и препараты, предназначенные для лечения сердечно-сосудистых заболеваний (60.0 \% ). Принимая во внимание то, что продолжительность лечения экстемпоральными лекарственными средствами колебалась от двух дней до месяца, наиболее повторяющейся продолжительностью была одна неделя. Витаминные сиропы аскорбиновой кислоты и комплекс витаминов В иногда используются в качестве основы для изготовления таких лекарственных средств, но исследования стабильности экстемпоральных препаратов, изготовленных из этих лечебных сиропов, в Нигерии не проводились. В 92.9 \% случаев для аптечного изготовления используются готовые лекарственные средства. Исследование стабильности лекарственных средств аптечного изготовления в Нигерии является актуальной проблемой, которая требует дальнейшего исследования.

Ключевые слова: экстемпоральные лекарственные средства; активный фармацевтический ингредиент; основа/наполнитель; анкетирование; сиропы; стабильность

УДК 615.014.2:615.2:615.451.2:615.11/.12

Д. С. Альфред-У гбенбо, О. А. Здорик, В. А. Георгіянц АНАЛІЗ РЕЦЕПТУРИ ЕКСТЕМПОРАЛЬНИХ ЛІКАРСЬКИХ ЗАСОБІВ У ГОСПІТАЛЬНИХ АПТЕКАХ ПІВДЕННОї НІГЕРІї

На теперішній час екстемпоральні лікарські засоби користуються все більшим попитом і виготовляються у комунальних і госпітальних аптеках всього світу, в тому числі Нігерії. Це пояснюється головним чином потребою індивідуального приготування лікарських засобів через вагу тіла, підбір дозування, труднощі при ковтанні, недоліки обміну речовин або відсутність необхідних лікарських форм. У Нігерії більшість (> 95 \% ) екстемпоральних лікарських засобів є пероральними лікарськими формами. Звичайною практикою для цих лікарських засобів є приготування з комерційно доступних пероральних твердих лікарських форм шляхом подрібнення таблеток або змішування вмісту з дисперсним середовищем (основою/наповнювачем). Метою роботи був аналіз номенклатури прописів, що найбільш часто виготовляються на півдні Нігерії, та проблеми вивчення стабільності лікарських засобів аптечного виготовлення, переліку основ/наповнювачів, що використовуються при виготовленні. 3 цією метою було проведено анкетування працівників госпітальних аптек в південно-південному геополітичному регіоні Нігеріі. Прописи, які вимагали екстемпорального виготовлення, були відібрані і розсортовані за активними фармацевтичними інгредієнтами, дозуванням, режимом і тривалістю лікування. Найбільш часто прописуються лікарські засоби аптечного виготовлення, що містять антибіотики (24.9%), і препарати, призначені для лікування серцево-судинних захворювань (60.0 \% ). Беручи до уваги те, що тривалість лікування екстемпоральними лікарськими засобами коливалася від двох днів до місяця, найбільш повторюваною тривалістю є один тиждень. Вітамінні сиропи аскорбінової кислоти та комплекс вітамінів В іноді використовуються в якості основи для виготовлення лікарських засобів, але дослідження стабільності таких екстемпоральних препаратів, виготовлених з цих лікувальних сиропів, у Нігерії не проводилося. У 92.9 \% випадків для аптечного виготовлення використовуються готові лікарські засоби. Дослідження стабільності лікарських засобів аптечного виготовлення в Нігерії є актуальною проблемою, що потребує подальшого дослідження.

Ключові слова: екстемпоральні лікарські засоби; активний фармацевтичний інгредієнт; основа/ наповнювач; анкетування; сиропи; стабільність

Адреса для листування:

Надійшла до редакції 28.03.2016 р.

61002, м. Харків, вул. Пушкінська, 53.

Тел. (0572) 67-91-97, 67-91-85.

E-mail: audeghinmotei@gmail.com;

oleksandr_zdoryk@ukr.net.

Національний фармацевтичний університет 